\title{
MONITORING OF HYDROCARBONS IN BENTHIC CRUSTACEANS DURING OFFSHORE DRILLING AND PETROLEUM EXPLORATION
}

\author{
Philip A. Meyers \\ Department of Atmospheric and Oceanic Science \\ The University of Michigan \\ Ann Arbor, Michigan, 48109 U.S.A.
}

(Received in USA 20 March 1978; received in UK for publication 20 April 1978)

\section{Introduction}

As part of a broad, multidisciplinary effort to monitor the impact of petroleum exploration activities on the outer continental shelf areas of the Gulf of Mexico, the local effects of a drilling rig on the benthic environment have been investigated. Petroleum hydrocarbons in or on seawater can become associated with suspended sediment particles $^{1}$ and be transported downward and incorporated into the bottom. In addition, cuttings settle around drilling sites. These processes can result in an alteration of sedimentary organic carbon characteristics of the type which has been documented in the vicinity of a petroleum production platform in the Gulf of Mexico ${ }^{2}$ and in accumulation of nonbiogenic hydrocarbons in the benthic enxironment. Crustaceans in this environment can rapidly take up petroleum hydrocarbons from the water or their food ${ }^{3}$ and can be adversely affected as summarized by Hyland and Schneider. ${ }^{4}$ For these reasons, the hydrocarbon contents of penaeid and stomatopod shrimp were determined in confunction with exploratory drilling operations as a measure of possible petroleum contamination of the benthos in this locality.

\section{Materials and Methods}

Organisms were collected by trawling at distances of $100 \mathrm{~m}, 500 \mathrm{~m}$, and $1000 \mathrm{~m}$ from a drilling rig located offshore of Mustang Island, Texas. Collection occurred during December 1975 prior to rig arrival, during January 1976 while exploratory drilling was being performed, and during March 1976 after removal of the rig. Identical sampling locations in four transects spaced $90^{\circ}$ apart and originating at the drilling site were occupied in each of the three collection periods. No petroleum or gas was found at this drill site, and no production has occurred as a result of this exploration operation.

Seventy samples representing 5 species of crustaceans were obtained. Each sample represents a pooled group of conspecific animals collected at a particular location in the sampling grid. These 70 samples were made up of 22 from the predrilling period, 18 from the drilling period, and 30 from the postdrilling collection period. Two specjes of decapod shrimp, Penaeus setiferus and Trachypenaeus similis, are represented in all three periods. Although present in the trawl collections, not enough individuals of the decapod shrimp Penaeus duoraroum nor of the stomatopods Squilla chydea or Squilla empusa were available to allow their analysis in every sampling perfod. Immediately after collection, animals were placed in solvent-rinsed glass jars topped with aluminum-foillined caps and $\mathrm{frozen}$. Samples were maintained at $-20^{\circ} \mathrm{C}$ or coider until analysis.

For analysis the entire pooled sample consisting of from 1 to 12 whole individuals was dried at $60^{\circ} \mathrm{C}$ to constant weight. The dried organisms were reduced to a homogeneous 
powder by crushing and stirring. A solution of $0.5 \mathrm{~N} \mathrm{KOH}$ in benzene/methanol, 50/50, was added, and this mixture sonicated for 10 minutes. Saponification of 1ipid matter and extraction and isolation of hydrocarbons proceeded after published methods.5,6 The nonsaponifiable lipids were extracted with petroleum ether after addition of water to the cooled saponffication mixture. Column chromatography using alumina over silica gel, $50 / 50$, separated saturated from unsaturated plus aromatic hydrocarbons. Gas-1iquid chromatography with a flame ionization detecter was employed to resolve and to quantify the various components of each hydrocarbon fraction. Both a non-polar column and a polar colum were used. The non-polar column was $4 \mathrm{~m} \times 2.1 \mathrm{~mm}$ ID $3 \% \mathrm{SP}-2100$ on $100-120 \mathrm{mesh}$ Supelcoport and was operated from $150^{\circ}$ to $325^{\circ} \mathrm{C}$ at $4^{\circ} \mathrm{C} /$ minute using nitrogen carrier gas at $15 \mathrm{ml} / \mathrm{minute}$. The polar column was $2.5 \mathrm{~m} \times 2.1 \mathrm{~mm}$ ID $10 \% \mathrm{SP}-1000$ mesh Supelcoport and was operated from $150^{\circ}$ to $250^{\circ} \mathrm{C}$ at $8^{\circ} \mathrm{C} /$ minute using nitrogen at a flow rate of $15 \mathrm{ml} /$ minute. These column packing materials are marketed by Supelco, Inc., Bellefonte, Pennsylvania. Retention times and integrated peak areas were entered into a computer program to calculate Kovats Indices relative to authentic standards and concentrations for each peak. Quantification was based upon a known amount of n-docosane added to each hydrocarbon fraction after column chromatography and prior to gas chromatography. Areas of unresolved envelopes were measured by planimetry. Blank determinations on the entire procedure were routinely determined and were small. The reported results have been corrected for these, nonetheless.

\section{Results and Discussions}

Hydrocarbon compositions of nearly all 70 samples were quite similar. A certain amount of variability was observed among individual samples, but the amount of resemblance was considerably larger than the amount of variability. This was surprising because not only were five different species of Crustacea being investigated, but these species included members of two separate orders, Decapoda and Stomatopoda, within this class. Furthermore, there appeared to be only minor differences between organisms collected from different sampling periods.

Representative chromatograms obtained from the saturated hydrocarbon fractions of samples of two organisms, Penaeus duoraroum and Squilla chydea, are shown in Fig. 1.
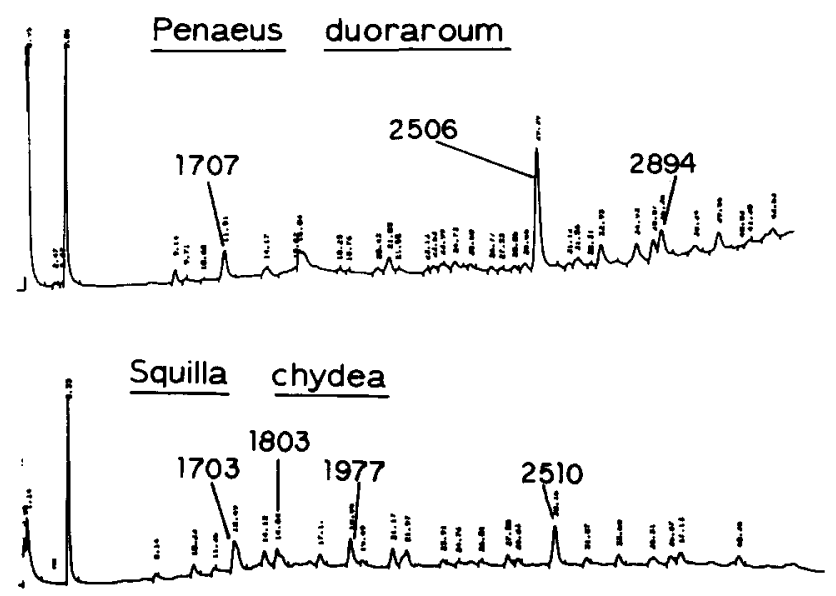

Figure 1. Representative Chromatograms of Saturated Hydrocarbons of Two Shrimps. Column conditions: 3\% SP2100 on 100-120 mesh Supel coport, $150-324^{\circ} \mathrm{C}$ at $4 \%$ minute. Peaks labelled by Kovats Index. 7 
Although the organisms are from different orders of Crustacea and were collected during different sampling periods, their traces are very similar. Both represent a fairly simple mixture of hydrocarbons that is well-resolved by this chromatographic column. The major peak in both traces is at a Kovats Index of 2506-2510. A major peak is not found at 2500 when these fractions are rechromatographed on polar columns, so the hydrocarbon represented by this peak is not n-pentacosane. In fact, few norma1 alkanes are found in any of the samples, and the saturated hydrocarbon compositions of these animals appear to be composed mostly of branched compounds.

The unsaturated hydrocarbon compositions of these organisms also display a fairly simple pattern. Usually 4 to 6 peaks dominate the chromatograms obtained from both nonpolar and polar colums. The major peaks of chromatograms of the saturated and unsaturated hydrocarbon fractions from representative samples of the 5 species are listed in Table 1 in terms of Kovats Retention Indices and weight percent contribution of each peak to the total fraction. Peaks from both polar and non-polar colums are listed. As shown

Saturated Hydrocarbons

Nonpolar Column Polar Column

Organism K.I. Wt.Pct. K.I

Penaeus setiferus $\quad 2248 \quad 15 \quad 2967$

2508

23

Wt.Pct.

\begin{tabular}{|c|c|c|c|c|c|c|c|c|}
\hline 2 & $\begin{array}{l}2271 \\
2508\end{array}$ & $\begin{array}{l}15 \\
23\end{array}$ & $\begin{array}{l}3013 \\
3140\end{array}$ & $\begin{array}{l}13 \\
19\end{array}$ & $\begin{array}{l}2114 \\
2143 \\
2274\end{array}$ & $\begin{array}{l}20 \\
11 \\
18\end{array}$ & $\begin{array}{l}2453 \\
2475 \\
2843\end{array}$ & $\begin{array}{l}14 \\
16 \\
14\end{array}$ \\
\hline Penaeus duoraroum & $\begin{array}{l}2506 \\
2894\end{array}$ & $\begin{array}{r}34 \\
8\end{array}$ & $\begin{array}{l}2343 \\
3145\end{array}$ & $\begin{array}{l}29 \\
26\end{array}$ & $\begin{array}{l}1950 \\
2133 \\
2300 \\
2477\end{array}$ & $\begin{array}{l}19 \\
15 \\
18 \\
11\end{array}$ & $\begin{array}{l}2224 \\
2244 \\
2461 \\
2810\end{array}$ & $\begin{array}{l}11 \\
11 \\
27 \\
16\end{array}$ \\
\hline Trachypenaeus similis & $\begin{array}{l}2506 \\
2894\end{array}$ & $\begin{array}{r}31 \\
7\end{array}$ & $\begin{array}{l}2495 \\
2798 \\
3144\end{array}$ & $\begin{array}{r}7 \\
8 \\
26\end{array}$ & $\begin{array}{l}1921 \\
2099 \\
2125 \\
2256\end{array}$ & $\begin{array}{l}14 \\
20 \\
10 \\
18\end{array}$ & $\begin{array}{l}2222 \\
2430 \\
2455 \\
2826\end{array}$ & $\begin{array}{l}16 \\
11 \\
18 \\
13\end{array}$ \\
\hline Squilla empusa & $\begin{array}{l}2244 \\
2249 \\
2507\end{array}$ & $\begin{array}{l}11 \\
11 \\
16\end{array}$ & $\begin{array}{l}2043 \\
2253\end{array}$ & $\begin{array}{l}35 \\
27\end{array}$ & $\begin{array}{l}1933 \\
2103 \\
2133 \\
2263 \\
2445\end{array}$ & $\begin{array}{l}20 \\
13 \\
11 \\
13 \\
10\end{array}$ & $\begin{array}{l}2234 \\
2438 \\
2463 \\
2833\end{array}$ & $\begin{array}{l}23 \\
12 \\
11 \\
10\end{array}$ \\
\hline Squilla chydea & $\begin{array}{l}1703 \\
1803 \\
1977 \\
2510\end{array}$ & $\begin{array}{r}15 \\
8 \\
10 \\
16\end{array}$ & $\begin{array}{l}1699 \\
1800 \\
2202 \\
3144\end{array}$ & $\begin{array}{r}8 \\
5 \\
11 \\
11\end{array}$ & $\begin{array}{l}1911 \\
2005 \\
2087 \\
2237\end{array}$ & $\begin{array}{r}10 \\
8 \\
13 \\
8\end{array}$ & $\begin{array}{l}2219 \\
2352 \\
2449 \\
2824\end{array}$ & $\begin{array}{r}14 \\
11 \\
11 \\
8\end{array}$ \\
\hline
\end{tabular}

Unsaturated Hydrocarbons

Table 1. Dominant Peaks in Chromatograms of Hydrocarbons from Uncontaminated Crustacean Samples. Peaks labelled by Kovats Index. ${ }^{7}$ See text for column descriptions.

in this tabulation, hydrocarbon compositions are dominated by only a few peaks, and some peaks having the same Kovats Indices are common to all five crustaceans. The largest peak from the non-polar chromatograms of the saturated fraction has an index of 25062510 in all 5 samples and indeed in most of the 70 samples in the total study. However, a peak having an index around 2500 is not a major contributor to polar chromotographs of this fraction. Instead, the most common major peak in these latter distributions has a Kovats Index of 2140-3144. Major peaks comprising the unsaturated fractions of the 
samples are grouped between Indices of 1900 to 2500 on the non-polar chromatograms. A shift to indices between 2200 to 2850 on polar chromatograms is indicative of the relatively polar nature of these unsaturated hydrocarbons.

A number of criteria are available ${ }^{8}$ to distinguish petroleun hydrocarbons from recently biosynthesized hydrocarbons in environmental samples such as these organisms. Three were employed in this study to determine petroleum contamination: (1) the presence of an unresolved complex mixture of saturated hydrocarbons, (2) the existence of a homologous series of n-alkanes, and (3) relatively high hydrocarbon concentrations. An unresolved complex mixture in hydrocarbons extracted from marine invertebrates has been considered diagnostic of petroleum in previous studies $5,6,9,10,11$, as has a uniform abundance of n-alkanes in the $\mathrm{C}-15$ to $\mathrm{C}-30$ range.9,10 In addition, animals contaminated by petroleum exhibit higher levels of total hydrocarbons than uncontaminated organisms normally contain. $9,11,12,13$

Nearly all of the 70 samples produced chromatograms which were free of an unresolved complex mixture of hydrocarbons and which lacked a homologous series of n-alkanes. Figure 1 is representative of the traces of this type. The only exceptions were two samples collected during drilling operations and two more collected in the postdrilling period. Chromatograms of the saturated and unsaturated fractions of one sample of Squilla chydea collected during the drilling period are presented in Fig. 2 . The
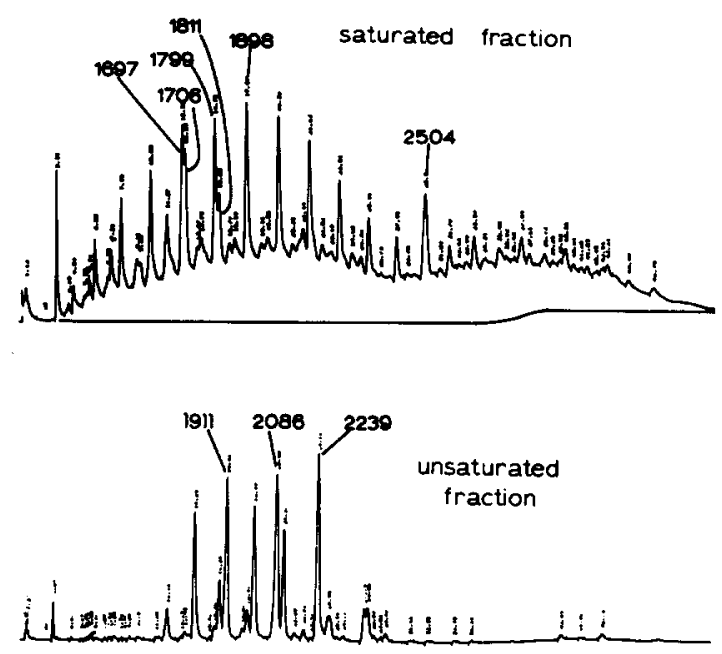

Figure 2. Chromatograms of Saturated and Unsaturated Hydrocarbons of Contaminated Sample of Squilla chydea. See Figure 1 for column conditions.

saturated fraction shows a large number of resolved peaks representing a homologous series of $n$-alkanes. A large envelope between these peaks and the baseline indicates the presence of a complex mixture of hydrocarbons unresolvable by this column. The unsaturated fraction exhibits only a limited number of peaks and no unresolved complex mixture in marked contrast to the saturated fraction. Simllar patterns and differences between fractions were found in the other three anomolous samples.

Kovats Indices and weight percent contributions to the total hydrocarbon fraction of 
the major peaks in two samples having unresolved envelopes are listed in Table 2 . The

Saturated Hydrocarbons

\begin{tabular}{|c|c|c|c|c|c|c|c|c|}
\hline Organism & $\begin{array}{c}\text { Nonpolar } \\
\text { K.I. }\end{array}$ & $\begin{array}{l}\text { Column } \\
\text { Wt.Pct. }\end{array}$ & $\begin{array}{l}\text { Polar } \\
\text { K.I. }\end{array}$ & $\begin{array}{c}\text { Column } \\
\text { Wt.Pct. }\end{array}$ & $\begin{array}{l}\text { Nonpolar } \\
\text { K.I. }\end{array}$ & $\begin{array}{l}\text { Column } \\
\text { wt.Pct. }\end{array}$ & $\begin{array}{l}\text { Polar } \\
\text { K.I. }\end{array}$ & $\begin{array}{l}\text { Column } \\
\text { Wt.Pct. }\end{array}$ \\
\hline Trachypenaeus similis & $\begin{array}{l}1701 \\
1710 \\
1802 \\
1815 \\
1903 \\
2003 \\
2103 \\
2203 \\
2303\end{array}$ & $\begin{array}{l}4 \\
4 \\
4 \\
3 \\
6 \\
7 \\
6 \\
4 \\
3\end{array}$ & $\begin{array}{l}1661 \\
1699 \\
1768 \\
1800 \\
1900 \\
2002 \\
2100 \\
2199 \\
2300\end{array}$ & $\begin{array}{l}4 \\
4 \\
3 \\
4 \\
5 \\
6 \\
5 \\
6 \\
4\end{array}$ & $\begin{array}{l}1922 \\
2099 \\
2126 \\
2256\end{array}$ & $\begin{array}{l}15 \\
20 \\
10 \\
17\end{array}$ & $\begin{array}{l}2230 \\
2438 \\
2464 \\
2830\end{array}$ & $\begin{array}{l}17 \\
12 \\
18 \\
12\end{array}$ \\
\hline Squilla chydea & $\begin{array}{l}1498 \\
1598 \\
1697 \\
1706 \\
1769 \\
1898 \\
1997 \\
2097 \\
2197 \\
2296 \\
2503\end{array}$ & $\begin{array}{l}5 \\
4 \\
5 \\
4 \\
5 \\
7 \\
7 \\
6 \\
4 \\
2 \\
4\end{array}$ & $\begin{array}{l}1599 \\
1659 \\
1698 \\
1766 \\
1798 \\
1899 \\
2000 \\
2098 \\
2197 \\
2297 \\
3143\end{array}$ & $\begin{array}{l}3 \\
5 \\
5 \\
4 \\
6 \\
6 \\
6 \\
5 \\
5 \\
3 \\
2\end{array}$ & $\begin{array}{l}1800 \\
1911 \\
2004 \\
2086 \\
2239\end{array}$ & $\begin{array}{l}10 \\
12 \\
11 \\
16 \\
16\end{array}$ & $\begin{array}{l}2135 \\
2215 \\
2349 \\
2446 \\
2822\end{array}$ & $\begin{array}{l}10 \\
12 \\
11 \\
12 \\
11\end{array}$ \\
\hline
\end{tabular}

Tab1e 2. Dominant Peaks in Chromatograms of Hydrocarbons from Contaminated Crustacean Samples. Peaks labelled by Kovats Index? See text for colum descriptions.

samples of Trachypenaeus similis and Squilla chydea were collected in the same trawl operation during January, 1976. The saturated fractions are composed of many peaks, none comprising more than $7 \%$ of the total fraction. Most of these peaks have retention indices corresponding to those of normal alkanes. This distribution is quite different from the listing of major peaks in Table 1 . where a limlted number of peaks are shown and few n-alkanes are indicated. In contrast to the saturated fractions, the unsaturated fractions of hydrocarbons of these two samples give only a few peaks. Furthermore, both the retention indices and welght percent contributions of the peaks are quite close to those of the same species listed in Table 1. This is true especially for $\underline{S}$. chydea.

The data in Table 2. and the chromatographic traces in Figure 2 Indicate hydrocarbon contamination of these samples by the presence of a homologous series of n-alkanes and an unresolved complex mixture of saturated hydrocarbons. It is interesting that no obvious change occurred in the unsaturated hydrocarbon fractions of these animals. However, this may indicate a difference in degree of effect rather than an actual lack of hydrocarbon contamination in the unsaturated fraction. Such a distinction arises because in all of the uncontaminated samples the concentrations of unsaturated hydrocarbons are two to three orders of magnitude greater than those of the saturated hydrocarbons. Thus, addition of equal amounts of contaminants of both fractions would have a greater effect upon the saturated fraction than on the unsaturated. Nonetheless, in this study it appears that the hydrocarbon contamination was primarily in the saturated fractions of the 4 samples which were anomalous.

This is shown in Table 3 in which concentrations of saturated and unsaturated frac- 
tions of representative samples are given relative to the dry weights of the samples. In

\begin{tabular}{lccc} 
Organism & $\begin{array}{c}\text { Saturated } \\
\text { Peaks }\end{array}$ & $\begin{array}{c}\text { Hydrocarbons } \\
\text { UCM }\end{array}$ & Unsaturated Hydrocarbons \\
\hline Penaeus setiferus & 5 & 0 & 896 \\
\hline Penaeus & 3 & 0 & 3299 \\
Trachyperaroum & 4 & 0 & 915 \\
Squilla chydea & 3 & 0 & 233 \\
Squilla similis & 2 & 0 & 840 \\
\hline Trachypenasa & 55 & 105 & 592 \\
\hline Squilla chydea & 30 & 60 & 234 \\
\hline
\end{tabular}

Table 3. Comparison of Hydrocarbon Concentrations in Uncontaminated and Contaminated Crustacean Samples. Concentrations given in $\mu$ gm hydrocarbons per gram dry welght of whole animal. UCM = unresolved complex mixture (see ref. 5).

uncontaminated samples, the concentration of resolved peaks in the saturated fractions totals between 2 to $5 \mathrm{\mu gm} / \mathrm{gm}$. No unresolved complex mixture is present in any of these samples. In contaminated samples, the concentrations of total resolved peaks are 10 times higher than in the natural populations, and unresolved complex mixtures which comprised about two-thirds of the total saturated hydrocarbons are present. However, no increases in unsaturated hydrocarbon concentration are found. In Squilla chydea, for example, this concentration $1 \mathrm{~s} 233 \mu \mathrm{gm} / \mathrm{gm}$ in the pristine sample and $234 \mu \mathrm{gm} / \mathrm{gm}$ in the contaminated one. Furthermore, as indicated in Figure 1, no unresolved complex mixture is displayed in the chromatogram of the unsaturated fraction of this or any of the other 3 contaminated samples. Thus, it seems that most, if not all, of the contamination is composed of saturated hydrocarbons.

\section{Conclusions}

Analysis of the hydrocatbon compositions of these 70 samples of crustaceans revealed only minor differences related to exploratory drilling operation. The samples contained both amounts and types of hydrocarbons which were relatively invariant, with the exception of 4 samples. These 4 samples, two of which were collected together, indicated petroleum hydrocarbon contamination. Because such contamination does not correlate well with either presence or absence of the drilling rig, it is difficult to conclude that contamination of these samples arose directly from drilling operations. It may be that this contamination occurred as a result of release of petroleum products used as fuels either by the rig itself or by ships around the rig.

Regardless of the specific source of the petroleum hydrocarbons, it is interesting that contamination was not detected prior to arrival of the drilling rig yet was found subsequent to its departure. Evidently, the presence of the rig resulted in contamination of parts of the benthic community by petroleum. It is significant that such contamination was readily detectable some 6 weeks after the rig and its associated ship activity had left the area. This suggests that the petroleum hydrocarbons had been incorporated into the tissues of the affected organisms and were not coatings which could be washed away. Thus, these materials had entered the local benthic food web and potentially could have sublethal deleterious effects upon these shrimps and their predators. 
This study has demonstrated the usefulness and efficacy of gas chromatography in identifying petroleum hydrocarbon contamination of organisms. It has also shown that in crustacean samples it is not feasible to monitor such contamination by determining hydrocarbon concentrations gravimetrically, because the amounts of saturated hydrocarbon contaminants found were very small relative to the total (saturated plus unsaturated) hydrocarbons in many of the samples. Finally, it must be observed that while gas chromatography is quite capable of detecting pollution, it would be scientifically highly desireable to identify the natural hydrocarbon components of samples such as those in this study by combined gas chromatography/mass spectrometry.

\section{Acknowledgements}

This study was supported by a subcontract from the State University System of Florida Institute of Oceanography under Contract Number 08550-CT5-30 from the U.S. Bureau of Land Management. Contribution Number 236 from the Department of Atmospheric and Oceanic Science of The University of Michigan.

\section{References}

1. P.A. Meyers and J.G. Quinn, Nature, 244: 23-24 (1973).

2. J.R. Gormlay and W.M. Sackett, Geophys. Res. Lett., 2: 197-200 (1975).

3. R.F. Lee, in Fate and Effects of Petroleum Hydrocarbons in Marine Organisms and Ecosystems, ed. D.A. Wolfe, Pergamon, Oxford, pp. 60-70 (1977).

4. J.L. Hyland and E.D. Schneider, in Sources, Effects, and Sinks of Hydrocarbons in the Aquatic Environment, Am. Inst. Biol. Sci, Washington, pp. 463-506 (1976).

5. J.W. Farrington, J.M. Tea1, J.G. Quinn, T. Wade, and K. Burns, Bul1. Environ. Contam. Toxico1., 10: 129-136 (1973).

6. J.W. Farrington, J.M. Teal, G.C. Medeiros, K.A. Burns, E.A. Robinson, Jr., J.G. Quinn, and T.L. Wade, Anal. Chem., 48: 1711-1716 (1976).

7. E.Kovats, in Advances in Chromatography, Vol. I, ed. J.C. Giddings and R.A. Keller, Dekker, N.Y. (1965).

8. J.W. Farrington, and P.A. Meyers, In Evyironmental Chemistry, Vol. 1, ed. G. Eglinton, The Chemical Society, London, pp. 109-136 (1975).

9. K.A. Burns and J.M. Teal, Deep-Sea Res., 20: 207-211 (1973).

10. M. Blumer, G. Souza, and J. Sass, Mar. Biol., 5: 195-202 (1970).

11. P.D. Boehm and J.G. Quinn, Mar. B101., 44: 227-233 (1977).

12. D.J. Scarratt and V. Zitko, J. Fish. Res. Bd. Canada, 29: 1347-1350 (1972).

13. L.H. DiSalvo, H.E. Guard, L. Hunter, and A.B. Cobet, in The Microbial Degradation of 011 Pollutants, ed. D.G. Ahearn and S.P. Meyers, Louisiana State Univ., Baton Rouge, pp. 205-220 (1973). 